\title{
Factors Affecting of Using Accounting Information System (AIS) on the Firm's Productivity: A Case Study Erbil, Iraq
}

\author{
Mikaeel Biro Munaf \\ Mustafa Farzenda Faris \\ Soran University \\ Faculty of Law \\ Political Science and Management \\ Accounting Department, Erbil \\ Iraq \\ Cuma Akbay \\ Kahramanmaraş Sütçü Imam University \\ Agricultural Faculty \\ Department of Agricultural Economics \\ Turkey
}

\begin{abstract}
The purpose of the study is to investigate factors affecting of using accounting information system (AIS) on the firm's productivity. An accounting data structure is a system that a business employs to collect, supervise, process, report and regain its financial relevant data, so that it may be very well used by business examiners, bookkeepers, administrators, advisors, Chief Financial Officers (CFOs), authoritative and charge organizations. The motivation behind the examination explored that factors influencing on Accounting Information System. The focused on test estimate for the study is 135 workers who selected randomly. The data were analyzed by using methods containing descriptive statistics and Chi-square test. The results showed that some factors, such as training expertise, firm size, learning application, monetary situation, expert improvement courses, and motivation of employees, significantly affect using the accounting information system on the firm productivity.
\end{abstract}

Keywords: Accounting Information Systems, Productivity, Erbil, Iraq.

\section{Introduction}

In general, the manual methodology is a clear reason for establishing accounting. There are some experience and knowledge of an individual bookkeeper, which are fundamental in bookkeeping appearance. Moreover, taking the manual methodology into the task can be unproductive and ineffective (Lucas, 1975). Accounting Information System sorts out a huge number of the abovementioned points. The AISs have the capability to supply automation of handling so many information and produce data accurately and on time. In the 1970s, due to the financial job traffics the old accounting information systems have been designed. (Bruns, 1968).

In the beginning, accounting information systems dominatingly have designed "in-house" as legacy systems. At that time, the protection of these kinds of systems was so expensive and tough to be up to date. Subsequently, most of the specialists in the accounting field preferred manual methodology rather than the computer-based system (Rom and Rohde, 2007). Nowadays, accounting information systems are sold as premade programming boxes from vast sellers, such as Sage Group and Microsoft, the places where it is designed and modified to be at the level of the institutions' business orders. Exclusive firms consistently operate accounting lower costs planning boxes such as Quick Books and MYOB. However, large institutions would constantly select enterprise resource planning systems (Brownell and Hirst, 1986). Although, the demand for network and hardening among other trade cycles inclined, accounting information systems have mixed with larger, more incorporated structures known as Enterprise Resource Planning (ERP). Previously, with the separate appeals to monitor diverse commerce capacities, associations needed to create comprehensive interfaces for the structures to contact each other (Urquía et al., 2011).

In enterprise resource planning, a structure, for instance, the accounting information system is worked as a unit integrated to a request of uses that can contain manufacturing, production network, HR (Lambert and Verrecchia, 2007). 
These measurement units are integrated and have the possibility to reach similar data and implement comprehensive commerce procedures. At present, there is a famous bookkeeping information system for both SMEs and actual institutions for lower costs, which called Cloud-based. With the reception of accounting information systems, a large number of companies have abandoned cheap talent, transactional and functional accounting roles (Soudani, 2012).

To describe an Accounting Information System, we can say that it is a system to collect, analyze, and preparing financial data, which is used by policy shapers. An accounting information system is commonly a PC founded method for supporters bookkeeping operation relevant to information upheaval property (Lieberman and Whinston, 1975). The following fiscal records can by directed inwardly by managers team or externally by other interested parties such as fiscal experts, loan bosses and outlay specialists. Accounting information systems are designed to aim every accounting capacities and exercises containing inspecting, fiscal bookkeeping, revelation, managerial accounting and duty. The most famous accepted accounting information systems are evaluating and revealing fiscal units (Leftwich, 1983).

Nowadays, the revolutionary development and data innovation located at the global free trade. However, they placed in the great economies in the world in general and in Erbil, Iraq in specifically have made the companies, including the Iraqi ones to adapt to these advancements on the one hand and the nearness of a solid aggressive condition occurring in firms sector on the other hand. The purpose of the study is to investigate factors affecting on accounting information system (AIS) on the firm's productivity.

\section{Methodology}

To acquire the vital information for the research, a questionnaire has been planned to apply to the workers in the province of Erbil in Iraq amid 2017. The focused on test measure for the investigation is 135 firm staff who chosen arbitrarily. Area A comprised of shut finished inquiries. Segments B and C utilized an organized 3-point adjusted Likert-scale battery of disagreeing (1), somewhat agree (2), agree (3) in accordance with. Information gathered by overseeing the exploration instrument was investigated in accordance with each examination question and hypothesis. Descriptive statistics were utilized to answer the exploration questions. The Chi-Square test was utilized to explain the hypotheses.

\section{Results and Discussion}

This section aims to investigate the information that was gathered through the survey with the end goal to assess the effects of accounting information system as a method of on firms working in the Erbil-Iraq. Table 1 shows that 56.3\% of the respondents are male. This indicated that the firms rely more on males in the firm's activities rather than females. According to the results, 54.8\% of the respondents in the sample categorized in 30-35 years old, which included the greatest part that firms use to hire workers with specific ages moderate. However, to take privileges of them for a long period of time and endow them with advanced skills and highly experienced with the transit of time. As illustrated in the Table 1, 9.6\% of the people beneath the category of 20-30 years old have taken second place. Afterwards, $35.6 \%$ of respondents are aged category of 35-40 years old, which illustrates that firms maintain a large proportion of employees with experience.

Table1. Socio Demographic Characteristics of Respondents

\begin{tabular}{|l|l|l|l|}
\hline Variables & Frequency & \% \\
\hline \multirow{3}{*}{ Gender } & Male & 76 & 56.3 \\
\cline { 2 - 4 } & Female & 59 & 43.7 \\
\hline \multirow{4}{*}{ Age group } & $20-30$ & 13 & 9.6 \\
\cline { 2 - 4 } & $30-35$ & 74 & 54.8 \\
\cline { 2 - 4 } & $35-40$ & 48 & 35.6 \\
\hline \multirow{5}{*}{ Job title } & Diploma & 19 & 14.1 \\
\cline { 2 - 4 } & Bachelor & 103 & 76.3 \\
\cline { 2 - 4 } & Master & 13 & 9.6 \\
\hline & Accounting manager & 11 & 8.1 \\
\cline { 2 - 4 } & Commercial manager & 36 & 26.7 \\
\cline { 2 - 4 } & Financial Manager & 15 & 11.1 \\
\cline { 2 - 4 } & Accountant & 48 & 35.6 \\
\cline { 2 - 4 } & Financial Editor & 25 & 18.5 \\
\hline
\end{tabular}

To demonstrate the respondents' accounting information system (AIS) elements, expressive statistics used to collect and gain the concept and standard divergence for each element. As shown in the Table 2, 6.8\% of employees disagree, $12.0 \%$ somewhat agree, and $81.2 \%$ agree about 'wage affects the employee motivation positively'. 
Furthermore, $14.1 \%$ of the employees selected disagree and increased to $35.6 \%$ somewhat agree about 'The employ of accounting information systems as an instrument to supervise all movements of the companies'. In the term of 'The resulting accounting information systems are elements to specify the level of credit to clients', $14.1 \%$ of employees disagree, $36.3 \%$ somewhat agree, and $49.6 \%$ agree.

Moreover, $9.6 \%$ of the employees chosen disagree and increased to $51.1 \%$ agree about 'preparing data sheltering all kinds of companies' actions at the lowest expenditure possible is gained through the Accounting Information Systems'. On other hands, $10.8 \%$ of the employees chosen disagree and increased to $44.8 \%$ agree about 'training and development positively affect employee'. As stated by the Table 2, 5.2\% of the employees selected disagree and increased to $51.1 \%$ agree about 'precise information produced by Accounting Information Systems on the monetary situation and give credence to the customer at the lowest feasible risk'.

Besides that, $63.7 \%$ of the employees chosen disagree and decreased to $14.1 \%$ agree on the term of 'there are some helps for administrators to improve processes and pragmatic goals by designing schemes and future strategies to confirm that accounting information systems will attain assumptions'.

Table. 2. Accounting Information System employee characters

\begin{tabular}{|c|c|c|c|c|c|}
\hline \multicolumn{2}{|l|}{ Variables } & Frequency & $\%$ & Mean & S.D \\
\hline \multirow{3}{*}{ Training } & Disagree & 25 & 18.5 & \multirow{3}{*}{2.23} & \multirow{3}{*}{0.743} \\
\hline & $\begin{array}{l}\text { Somewhat } \\
\text { agree }\end{array}$ & 54 & 40.0 & & \\
\hline & Agree & 56 & 41.5 & & \\
\hline \multirow{3}{*}{ Tool to monitor all activities } & Disagree & 19 & 14.1 & \multirow{3}{*}{2.36} & \multirow{3}{*}{0.719} \\
\hline & $\begin{array}{l}\text { Somewhat } \\
\text { agree }\end{array}$ & 48 & 35.6 & & \\
\hline & Agree & 68 & 50.4 & & \\
\hline \multirow{3}{*}{ Determine the degree of credit to clients } & Disagree & 19 & 14.1 & \multirow{3}{*}{2.36} & \multirow{3}{*}{0.717} \\
\hline & $\begin{array}{l}\text { Somewhat } \\
\text { agree }\end{array}$ & 49 & 36.3 & & \\
\hline & Agree & 67 & 49.6 & & \\
\hline \multirow{3}{*}{ Types of firms operations at the lowest cost } & Disagree & 13 & 9.6 & \multirow{3}{*}{2.41} & \multirow{3}{*}{0.662} \\
\hline & $\begin{array}{l}\text { Somewhat } \\
\text { agree }\end{array}$ & 53 & 39.3 & & \\
\hline & Agree & 69 & 51.1 & & \\
\hline \multirow{3}{*}{ Expertise } & Disagree & 6 & 4.4 & \multirow{3}{*}{2.81} & \multirow{3}{*}{0.496} \\
\hline & $\begin{array}{l}\text { Somewhat } \\
\text { agree }\end{array}$ & 14 & 10.4 & & \\
\hline & Agree & 115 & 85.2 & & \\
\hline \multirow{3}{*}{$\begin{array}{l}\text { Monetary situation and give credence to the customer at the } \\
\text { lowest feasible risk }\end{array}$} & Disagree & 7 & 5.2 & \multirow{3}{*}{2.46} & \multirow{3}{*}{0.596} \\
\hline & $\begin{array}{l}\text { Somewhat } \\
\text { agree }\end{array}$ & 59 & 43.7 & & \\
\hline & Agree & 69 & 51.1 & & \\
\hline \multirow{3}{*}{ Firm size } & Disagree & 84 & 62.2 & \multirow{3}{*}{1.45} & \multirow{3}{*}{0.631} \\
\hline & $\begin{array}{l}\text { Somewhat } \\
\text { agree }\end{array}$ & 41 & 30.4 & & \\
\hline & Agree & 10 & 7.4 & & \\
\hline \multirow{3}{*}{ Knowledge application } & Disagree & 33 & 24.4 & \multirow{3}{*}{2.15} & \multirow{3}{*}{0.787} \\
\hline & $\begin{array}{l}\text { Somewhat } \\
\text { agree }\end{array}$ & 49 & 36.3 & & \\
\hline & Agree & 53 & 39.3 & & \\
\hline \multirow{3}{*}{$\begin{array}{l}\text { Helps for administrators to improve processes and } \\
\text { pragmatic goals by designing schemes and future strategies }\end{array}$} & Disagree & 86 & 63.7 & \multirow{3}{*}{1.50} & \multirow{3}{*}{0.732} \\
\hline & $\begin{array}{l}\text { Somewhat } \\
\text { agree }\end{array}$ & 30 & 22.2 & & \\
\hline & Agree & 19 & 14.1 & & \\
\hline
\end{tabular}

The link among employee specifications and accounting data cycle is shown in Table 3. However, it statistically indicates a crucial impact over the motivation of employees and accounting data structure such as training, expertise, knowledge application, and firm's size. 
Nevertheless, outcomes statistically reveal that there is a vital linkage between training and accounting data structure $(\chi 2=22.143 ; \mathrm{P}=0.000)$. According to result, $9.0 \%$ of the respondents chose agree about training and increased to $38.8 \%$ satisfied on the case of accounting fact cycle.

Further, the products represented that the relationship between expertise and accounting Information System $\left(\chi^{2}\right.$ $=24.157 ; \mathrm{P}=0.000$ ) is significant. Moreover, nearly $43.0 \%$ of the employees selected somewhat agree about expertise and decreased to $10.5 \%$ satisfied on the term accounting information system. The results showed that there is a significant linkage between knowledge application and accounting data structure $\left(\chi^{2}=19.827, \mathrm{P}=0.001\right)$. The result indicated that nearly $60 \%$ of the employees chose agree about knowledge application and increased to $31.6 \%$ satisfied on the term of satisfied in subject of accounting information system.

By looking at the result, a significant relationship can be seen between firm's size and accounting information system $\left(\chi^{2}=17.207 ; \mathrm{P}=0.002\right)$. The highest percentage of respondents which were $57.9 \%$ chose disagree in the term of firm's size and increase to $63.3 \%$ of them somewhat satisfied about accounting data structure.

Table 3. Relationship between Accounting Information Structure and Firm's Productivity

\begin{tabular}{|c|c|c|c|c|c|c|c|}
\hline \multirow{2}{*}{\multicolumn{2}{|c|}{ Variables }} & \multicolumn{4}{|c|}{ Accounting Information System } & \multirow[b]{2}{*}{$x^{2}$} & \multirow[b]{2}{*}{$\begin{array}{l}P \text { - } \\
\text { value }\end{array}$} \\
\hline & & Dissatisfied & $\begin{array}{l}\text { Somewhat } \\
\text { satisfied }\end{array}$ & Satisfied & Total & & \\
\hline \multirow{3}{*}{ Training } & Disagree & 50.6 & 21.1 & 26.3 & 100.0 & \multirow{3}{*}{22.143} & \multirow{3}{*}{0.000} \\
\hline & Somewhat agree & 12.2 & 53.1 & 39.7 & 100.0 & & \\
\hline & Agree & 9.0 & 52.2 & 38.8 & 100.0 & & \\
\hline \multirow{3}{*}{ Expertise } & Disagree & 42.1 & 47.4 & 10.5 & 100.0 & \multirow{3}{*}{24.157} & \multirow{3}{*}{0.000} \\
\hline & Somewhat agree & 22.4 & 42.9 & 34.7 & 100.0 & & \\
\hline & Agree & 4.5 & 37.3 & 58.2 & 100.0 & & \\
\hline \multirow{3}{*}{$\begin{array}{l}\text { knowledge } \\
\text { application }\end{array}$} & Disagree & 36.8 & 31.6 & 31.6 & 100.0 & \multirow{3}{*}{19.827} & \multirow{3}{*}{0.001} \\
\hline & Somewhat agree & 12.2 & 46.9 & 40.8 & 100.0 & & \\
\hline & Agree & 3.0 & 37.3 & 59.7 & 100.0 & & \\
\hline \multirow{3}{*}{ Firm size } & Disagree & 57.9 & 31.6 & 10.5 & 100.0 & \multirow{3}{*}{17.207} & \multirow{3}{*}{0.002} \\
\hline & Somewhat agree & 14.3 & 63.3 & 22.4 & 100.0 & & \\
\hline & Agree & 31.3 & 37.3 & 31.3 & 100.0 & & \\
\hline
\end{tabular}

\section{Conclusion and Recommendation}

An electronic system contains all reports that a firm uses to prepare financial statements and that one may use to protect against a review. Bookkeeping records incorporate receipts, records, deals records, etc. An accounting information system has turned into a noteworthy means for a firm to keep up accounting records. The motivation behind the research explored that factors influencing on Accounting Information System on the company's efficiency. This investigation aims to decide distinguishing proof of the reasons that reason accounting system Information workers in Erbil-Iraq. The statistical analysis had been utilized for straight out factors to indicate frequencies and percentages. To discover the connection between the categorical variables, Chi-Square used test was used. According to test results, there is significant association between training expertise, knowledge, firm size, learning application, monetary situation and using the accounting information system on the firm productivity.

\section{References}

Lucas, H.C., 1975. The Use of an Accounting Information System, Action and Organizational Performance. The Accounting Review, 50(4): 735-746.

Lieberman, A.Z. and Whinston, A.B., 1975. A Structuring of an Events-Accounting Information System. The Accounting Review, 50(2): 246-258.

Soudani, S.N., 2012. The Usefulness of an Accounting Information System for Effective Organizational Performance. International Journal of Economics and Finance, 4(5): 136.

Leftwich, R., 1983. Accounting Information in Private Markets: Evidence from Private Lending Agreements. Accounting Review: 23-42.

Rom, A. and Rohde, C., 2007. Management Accounting and Integrated Information Systems: A Literature Review. International Journal of Accounting Information Systems, 8(1): 40-68.

Lipe, R., 1990. The Relation between Stock Returns and Accounting Earnings Given Alternative Information. Accounting Review: 49-71. 
Brownell, P. and Hirst, M., 1986. Reliance on Accounting Information, Budgetary Participation, and Task Uncertainty: Tests of a Three-Way Interaction. Journal of accounting Research: 241-249.

Mock, T.J., 1971. Concepts of Information Value and Accounting. The Accounting Review, 46(4): 765-778.

Bruns, W.J., 1968. Accounting Information and Decision-Making: Some Behavioral Hypotheses. The Accounting Review, 43(3): 469-480.

Lambert, R., Leuz, C. and Verrecchia, R.E., 2007. Accounting Information, Disclosure, and the Cost of Capital. Journal of accounting research, 45(2): 385-420.

Urquía Grande, E., Pérez Estébanez, R. and Muñoz Colomina, C., 2011. The impact of Accounting Information Systems (AIS) on performance measures: empirical evidence in Spanish SMEs. 